GC/MS for Environmental Analysis, organized by Paul C. Goodley and Norman Low

Practical MS/MS, instructed by Jodie Johnson and Richard A. Yost

LC/MS, organized by Robert D. Voyksner and Alfred Yergey.

\section{THE 11TH ASILOMAR CONFERENCE ON MASS SPECTROMETRY}

The 11th Asilomar Conference on Mass Spectrometry will be held September 24-28, 1995, at the Asilomar Conference Center in Pacific Grove, CA. The topic will be Molecular Structure Determination: Activation, Mass Analysis, and Detection. Fundamental understanding of activation methods, ion/molecule reactions and collision processes continues to advance. The ion chemistry of multiply charged ions is being developed. New experiments such as ion/surface collisions provide information on ion structures. Improvements in techniques for ionization and mass analysis continue to occur. All these developments offer opportunities to further improve mass spectrometry in chemical and biochemical analysis. These are the subjects to be treated at the 1995 Asilomar Conference.

The purpose of the Asilomar Conference on Mass Spectrometry is to provide a forum for an international group of scientists for in-depth and informal discussion of the most recent developments in a subfield of mass spectrometry, with the intent of stimulating creativity, critical thinking, and exchange of ideas. The 11th ACMS will be concerned with methods of structure determination, especially for biomolecules. All oral and poster presentations will be by invited contributors only. The conference is formatted to encourage uninhibited discussions and extensive audience participation. The campus-style setting of Asilomar, located on the scenic Monterey Peninsula as a unit of the California State Park System, offers an ideal environment for informal meetings and recreational activities. For further information please contact ASMS, 1201 Don Diego Avenue, Santa Fe, NM 87505. Telephone: (505) 989-4517.

\section{RELATED EVENTS}

ASMS is happy to announce meetings of non-profit organizations. Please supply date, name of event, and location, along with the full address, telephone number and fax of contact person. You may also include a brief description, not to exceed one paragraph of 300 characters.

1995

May 21-26

43rd ASMS Conference on Mass Spectrometry and Allied Topics, Atlanta Marriott Marquis, Atlanta, Georgia. Contact: ASMS, 1201 Don Diego Avenue, Santa
July 9-13

August 7-18

May 22-24

Fe, NM 87505. Phone: (505) 9894517. Fax: (505) 989-1073.

The Eighth International Symposium on Polymer Analysis and Characterization (ISPAC-8), Sundial Beach Resort, Sanibel Island, FL. Contact: ISPAC 1201 Don Diego Avenue, Santa $\mathrm{Fe}$, NM 87505. Phone: (505) 989-4517. Fax: (505) 989-1073.

3rd International Symposium on Applied Mass Spectrometry in the Health Sciences and 3rd European Tandem Mass Spectrometry Conference to be held in Barcelona, Spain. Topics will include: New developments in MS instrumentation and novel techniques; Development in tandem MS; Excitation and fragmentation of ions; High mass methods for biomolecules; Recent trends and horizons in combined chromatographic and MS techniques and applications in clinical, metabolic and biochemical studies; Molecular biology and biotechnology; environmental and feed chemistry; Toxicology and doping control; Drug assay methods and pharmacology; Fundamental studies and fragmentation mechanisms of biomolecules. For further information, contact Prof. Emilio Gelpi, Palau de Congressos, Dept. de Convencions, Avda. Reina Cristina, 08004 Barcelona, Spain. Telephone: 343-4233101, Ext. 8208-8213. Fax: 343-4262845.

A NATO Advanced Study Institute (ASI) "Fundamentals and Applications of Gas-Phase Ion Chemistry" will be held at Hotel an Badersee, Grainau, GarmischPartenkirchen, Germany. An ASI is a high-level teaching activity for 100 persons of which approximately 15 are senior lecturers. Some support is available to help defray costs of attending. In North America contact: Professor Terrance McMahon, Department of Chemistry, University of Waterloo, Waterloo, Ontario, Cànada N2J 3G1; Phone (519) 885-1211, ext. 2129; Fax (519) 746-0435; E-Mail: MCMAHON@WATS CHI.UWATERLOO.CA. All others contact Professor Keith 
August $18-20$

September 12-14 The French mass spectrometry society has chosen Bordeaux as the site of its next congress: " $12^{\text {èmes }}$ Journées Francaises de Spectromerrie de Masse." For more information contact Dr. Guy Bourgeois, CESAMO, Université Bordeaux-1, F-33405 Talence Cedex; Phone (33) 568464 49; Fax (33) 56842623.

September 24-28 11th Asilomar Conference on Mass Spectrometry, Molecular
Structure Determination: Activation, Mass Analysis and Detection, Asilomar Conference Center, Pacific Grove, CA. Contact: ASMS, 1201 Don Diego Avenue, Santa Fe, NM 87505. Phone: (505) 989-4517. Fax: (505) 989-1073.

September 24-29 ANZSMS-15, Sydney, Australia, 15th Conference of The Australian and New Zealand Society for Mass Spectrometry. Details are available from Assoc. Prof. Michael Guilhaus, ANZSMS-15 Secretary, School of Chemistry, The University of New South Wales, Sydney 2052, Australia; phone 023854717 ; fax 02385 5958; email M.Guilhaus@unsw. edu.au. The conference will be held on the campus of The University of New South Wales and has the following areas of focus: Biological Mass Spectrometry, Drugs in Sport, Ion Chemistry, Environmental Mass Spectrometry, ICP/MS, Mass Spectrometry and the Earth Sciences.

November 1-3 12th Liquid Chromatography/ Mass Spectrometry "Montreux" Symposium to be held at Hilton Head Island, South Carolina. Short course will be held October 30-31. For further information contact: Robert Voyksner, Research Triangle Institute, P.O. Box 12194, Research Triangle Park, NC. Telephone: (919) 541-6697. FAX: (919) 541-7208. 